\title{
Social Protection Priorities for Internal Migrants in Kharkiv Region, Ukraine
}

\section{H. Kuts (Halyna Kuts)1', V. Nakonechny (Volodymyr Nakonechny)2, Y. Kuts (Yurii Kuts)², O. Sergeyeva (Olena Sergeyeva)²}

${ }^{1}$ Kharkiv National Pedagogical University by G. S. Scovoroda, Ukraine. Original Article

${ }^{2}$ Kharkiv Regional Institute of Public Administration of the National Academy of Public Administration of Ukraine under the President of Ukraine, Ukraine.

\section{E-mail address:}

kuts.niss@gmail.com

\section{Reprint address:}

Halyna Kuts

Kharkiv National Pedagogical University by G. S. Scovoroda

Faculty of Psychology and Sociology

Alchevskyh Str., 29

61002, Kharkiv

Ukraine

Source: Clinical Social Work and Health Intervention Pages: 7 - 13

Volume: 11

Issue: 4

\section{Reviewers:}

Daria Kimuli

Catholic University of Eastern Africa, Nairobi, Kenya

Selvaraj Subramanian

SAAaRMM, Kuala Lumpur, Malaysia

\section{Keywords:}

Internal migrants. Social assistance. Internally Displaced Persons (IDPs). Armed conflict. Ukraine. Kharkiv.

\section{Publisher:}

International Society of Applied Preventive Medicine i-gap

CSWHI 2020; 11(4): 7 - 13; DOI: 10.22359/cswhi_11_4_01 C Clinical Social Work and Health Intervention

\section{Abstract:}

Background. In 2014, an armed conflict began in the eastern territories of Ukraine. In Kharkiv region, there are one of the highest numbers of internal migrants in need of social assistance in Ukraine.

Objective is to define effective strategies of social service provision to internal migrants (or internally displaced persons in Kharkiv region.

Methods. General scientific methods and special scientific 
methods (content analysis method and others) are applied. The analysis of the secondary sociological information array concerning the problems of social protection of internally displaced persons in Ukraine and Kharkiv region.

Results. It is argued that the social assistance project „Helping Hand" has become the most successful in the social field for IDPs.

Conclusions. The most successful projects on providing social assistance to internal migrants in Kharkiv are highlighted: in employment and housing spheres. The focus on organizational issues in obtaining social services for internal migrants is made.

\section{Introduction}

In 2014, an armed conflict began in eastern Ukraine, as a result leaving part of Donetsk and Luhansk regions beyond the control of the Ukrainian state. The fighting in eastern Ukraine has threatened the lives of thousands of people so they have been forced to flee their homes. The official website of the Ministry of Social Policy of Ukraine states: „Since 2014, Ukraine has been in a state of undeclared war. Some of its territories are illegally annexed by the neighboring state, some are temporarily occupied by the same aggressor, hostilities are taking place on part of the territory. Almost one and a half million citizens of Ukraine were forced to leave their homes and move to the territory under the control of the Ukrainian authorities in search of protection, and often of a mere rescue“ (1).

These events determined the unprecedented internal and external displacement of a large number of the Ukrainian population. „In the Ukrainian scientific literature, in media these people are referred to as ,internal migrants“, ,forced migrants“, in official documents - ,internal migrants", which most closely corresponds to the English term ,internally displaced persons (IDPs)“" (2, p. 264). Thus, in the legislation of Ukraine, these internal migrants who left ,their place of residence as a result or in order to avoid the negative effects of armed conflict (3) are referred to as ,internally displaced persons“ (IDPs).

According to the United Nations, as of June 2015, there were 1.4 million internal migrants (internally displaced persons) registered in Ukraine. Moreover, Ukraine ranks ninth in the world in this indicator (4, p. 275).

Currently, the situation has not changed ut- terly. Currently, the situation has changed very little. As of April 13, 2020, the number of internally displaced persons in Ukraine is $1,446,881$ (5). These are IDPs from the temporarily occupied territories of Donetsk and Luhansk regions and the Autonomous Republic of Crimea. Of these: 367,849 persons are working age; 197, 672 children; 51,355 persons with disabilities; 724,427 - pensioners; 1,173,283 families.

Today Kharkiv region is a border territory with Russia and a frontline region bordering both Donetsk and Lugansk regions where hostilities continue. In Kharkiv region there is one of the highest indicators of the number of internally displaced persons (IDPs) due to the armed conflict in the Donbas (Donetsk and Lugansk regions). The calculation of real data on the number of internal migrants arriving to Kharkiv region from the area of armed conflict is quite complicated. In Kharkiv region in August 2015, the total number of internally displaced persons was 185,600 (6, p. 40). In February 2016, 212,600 IDPs were officially registered. However, at the same time, the administration of Kharkiv region has repeatedly stated that, along with undocumented internal migrants, there are more than 300,000 internally displaced persons in the region (7, p. 124).

As of 02.04.2020 (8), 134,111 internally displaced persons (108,361 families) have been registered by the social protection authorities in Kharkiv region. The forced internal migration of the population from some regions of Donetsk and Lugansk regions and the Autonomous Republic of Crimea to other regions of Ukraine has caused many different problems. One of the most important problems for IDPs has been that of social protection. 


\section{Situation with social protection of internal migrants in Kharkiv region, Ukraine}

For the optimal consideration of the level of social protection of internally displaced persons (internal migrants) in Kharkiv region, let us turn to the analysis of sociological research. Let us analyze those sociological surveys whose respondents, on the one hand, were representatives of social services and, on the other, forced migrants.

A social survey was conducted in Kharkiv in October 2015 to identify problems in the activities of the municipal social services in dealing with internally displaced persons (6, p. 41). In general, Kharkiv was ready to welcome inland migrants. Also the city's population attitude toward the IDPs was also quite positive. It was noted that a significant part of social service workers actively involve volunteers in working with internally displaced persons.

However, internally displaced persons faced a variety of problems. They needed additional social services'; the creation of additional organizational structures to provide these services for example, counseling points where they could get legal assistance; social and rehabilitation centers; groups where advice from people with similar experience could be obtained and so on. The fact is that there were no new social protection services for migrants from the conflict zone in Kharkiv (as in Ukraine as a whole). Already existing social services urgently reoriented their activities to help IDPs arriving in Kharkiv since the spring 2014.

It should be noted that later (in 2017), three new large social service centers "Prozory Ofis“ (Transparent Office) were established in Kharkiv, where internally displaced persons from the area of armed conflict are provided with a wide range of necessary social services.

Housing, registration and employment services for internally displaced persons have become the most complex services for Kharkiv social service workers. In particular, finding a job for many IDPs has been a big problem.

On the whole, the workload of social workers in Kharkiv region has increased and its context has changed due to the need to provide new social services to a new social group - internal migrants. Yet, the overwhelming majority of social workers at that time did not receive additional funding $(6, \mathrm{p} .45)$.
A sociological survey, conducted among internal migrants in Kharkiv region in 2016, stated that the most common problems faced by IDPs were ,housing, access to health care, and underemployment“" (7, p. 126).

A previous sociological survey conducted in the city of Kharkiv in January-February 2015 among internally displaced persons who sought help from the charitable organization „Caritas“ also saw the most acute problems of lack of housing and underemployment. The IDPs were found to be in a very difficult financial situation. For $84 \%$ of respondents, lack of their own housing is a major problem. Next in importance were the following problems: „lack of funds for the most necessary things (38\%); lack of work in general $(30 \%)$; lack of necessary clothing $(29 \%)^{\prime \prime}$ (4, p. 278). According to the study, internally displaced persons mostly relied on themselves (47\%) and support of their relatives (29\%) in solving material problems. Equal were the proportions of persons who relied on financial support from the state and volunteers.

The socio-demographic portrait of internally displaced persons in Kharkiv region can be described in general terms. A 2016 study found that ,among newcomers, $25.4 \%$ are people aged 35 to 44 , the least represented demographic is young people $(7.2 \%)$ and older people $(8.1 \%)$ “ (7, p. 125). By gender, in Kharkiv region there were more women $(70 \%)$ than men $(30 \%)$.

It is interesting to look at the distribution by occupational groups: the most represented was the group of managers, specialists and employees were $61.6 \%$ of those displaced to Kharkiv region (7, p. 125). These data correlate with the level of education of internal migrants: $72 \%$ have higher education; $17 \%$ - vocational education; $11 \%$ secondary education.

The high educational level of internal migrants who moved to Kharkiv region is also highlighted in another previous sociological survey conducted in 2015. It revealed that more than half of the respondents have higher education. Also, the results of the survey showed that every tenth respondent held a management position at the level of an institution or subdivision of an enterprise» (4, p. 278). That is, it can be assumed that forced migrants with a high level of education also had a corresponding high professional status before leaving their place of permanent residence. 
Overall, large-scale internal migration in Ukraine has caused both objective and subjective consequences for internal migrants (7, p. 33). First and foremost, is about increasing competition in the labor market affecting locals who had become hosts for IDPs. Demand for rental housing also increased significantly. Overload of health care and educational institutions was observed.

Thus, the most pressing problems, which internal migrants in Kharkiv region have faced, are lack of housing and underemployment for internally displaced persons from armed conflict.

\section{The results of basic directions of social assistance to internal migrants in Kharkiv region}

One of the successful projects to assist internally displaced persons from the area of armed conflict in the Kharkiv region is the project „Ruka Dopomohy“ (Helping Hand), which has been operating in the region since 2017 . This project was implemented by the Ministry of Social Policy of Ukraine with the support of the World Bank which is being implemented as part of a broader strategy of modernizing the system of social support for the population. The goal of the „Helping Hand“ project is to help „IDPs and needy families' dependents get rid of welfare payments reliance; to get a decent job or start their own business" (9). Therefore, the key objective of the project is to bring back IDPs to the labor market. The „Helping Hand project involves engaging participants in economic activity, taking into account the particularities and aspirations of each. For Ukraine, this is an entirely new mechanism of social protection. At the same time, such projects have proved their effectiveness and efficiency in the countries of the European Union.

In Kharkiv region, one of the mechanisms of the „Helping Hand project has become provision of zero-interest reimbursable financial assistance (microcredits) to those participants who dream of setting up their own business.

During 2017-2018, 1,000 internally displaced persons participated in the project in Kharkiv region. About 500 internal migrants were employed or engaged in community service. It should be noted that the „Helping Hand“ project offers employment assistance to people who are looking for a stable income. However, if there is no desired vacancy at the time of application, the project offers various options for temporary paid work for the benefit of the community.

48 internally displaced persons received financial assistance and became entrepreneurs in the Kharkiv region. It is interesting to note that with the help the project already existing businesses have created 44 jobs for migrant workers. The support of the „Helping Hand“ project participants and consultancy assistance have continued today: in particular of those entrepreneurs, the vast majority of whom are effectively developing their businesses and paying taxes.

A characteristic of the „Helping Hand“ project is to encourage local businesses to create new jobs. If representatives of a particular local business employ two project participants, the enterprise itself can receive interest-free loans from the state for the purchase of new equipment.

The „Helping Hand“ project has been the most successful one in the social field for those people who have moved from the conflict zone to Kharkiv. Illustrative in this context is the example of Alina Starchenko, who used to live in Luhansk region. With the start of hostilities in Luhansk region, Alina left her home and moved to Kharkiv. With a college degree in economics she was looking for a new job. Before the war she had worked as an accountant. Alina Starchenko decided to start her own business and applied for employment assistance to Kharkiv City Employment Center (10). Because she had the status of an internally displaced person, she was invited to take part in the pilot project „Helping Hand“ at the Employment Center. Alina successfully wrote and defended a business plan on furniture production. Shortly, she received a lump sum unemployment payment. With this money she purchased furniture manufacturing equipment. Today, Alina Starchenko together with her husband and employees are making baby beds and planning to expand production capacity.

Since 2016, important projects have been implemented in Kharkiv region to help solve the urgent problems of internally displaced persons. In particular, these are the following projects: a pilot project on involvement of low-income families and internally displaced persons in accordance with the Resolution of the Cabinet of Ministers 
of Ukraine No. 1154 dated December 2, 2015 (as amended); a project „Entrepreneurial Initiatives Development Center in Kharkiv“ (implemented with the support of the International Renaissance Foundation); projects of the Caritas-Kharkiv Charitable Foundation (11).

The „Livelihoods“ project under the auspices of the Caritas-Kharkiv Charitable Foundation (11) has become interesting in terms of solving the internal migrants' employment problems. This project started in September 2015 for the employment of internally displaced persons - „Career for New Life“. The purpose of the project was to provide comprehensive assistance to displaced persons addressing employment and integration issues in the new community. The „Livelihoods“ project has several areas of assistance for internally displaced persons: providing initial consultation to identify customer requests; employment assistance; creation of a beneficiary base; assisting with resume writing; assistance in matching job vacancies in accordance with the experience and wishes of clients and in accordance with the current labor market. The careerfornewlife.com employment site provides online counseling to internally displaced persons within the project. Internal migrants are also provided with individual grants for vocational training to enhance their employment opportunities.

In 2016, out of the total number of internally displaced persons employed in Kharkiv region, employees $(51.5 \%)$ were more successful, and the percentage of employment of workers was $35.1 \%$ (7, p. 125). This was due to the fact that the workers in the Donbass (Donetsk and Luhansk regions) had mostly worked in the mines. As there are no mines in Kharkiv region, workers who had been displaced had to acquire new skills and look for new jobs. In Kharkiv region, agriculture, processing and trade account for the largest number of employed internal migrants.

Quite the most difficult problem for majority of internally displaced persons is housing. In Kharkiv region, compact settlements were organized for the displaced persons from the armed conflict zone: modular settlements; temporary settlements; etc. „Affordable Housing“ and „Homeownership“" programs were also funded to provide housing for internally displaced persons in urban and rural areas (2, p. 266).
Kharkiv City Council approved „Socio-Economic Municipal Target Program for Construction (Acquisition) of Affordable Housing for 2010-2025“. Under this program, internally displaced persons are eligible for preferential loans for the construction or purchase of affordable housing.

On the issue of housing for internally displaced persons, Kharkiv Regional State Administration cooperates with international organizations. Within the framework of the project „Promotion of Social Infrastructure Development (USIF V)“ with the support of Ministry of Economic Development and Cooperation of Germany (BMZ) and Credit Institute for Reconstruction (KfW) 6 micro-projects for reconstruction of residential buildings for internally displaced persons are underway in Kharkiv region in the towns of Bohodukhiv, Krasnograd, Lozova, Dergachi, Izyum, village of Zolochiv (12).

At the same time, in Ukraine the implementation of the state policy on ensuring the rights of internal migrants is characterized by the lack of a strategic vision on the issue of housing for them.

\section{Conclusions}

Today Kharkiv region is a border area with Russia and a frontline with both Donetsk and Lugansk regions, where hostilities have been taking place since 2014. The fighting in eastern Ukraine has threatened the lives of thousands who were forced to flee their homes. In Kharkiv region, there is one of the highest numbers of internal migrants in need of social assistance in Ukraine.

Priorities in social protection of internal migrants in Kharkiv region were identified: housing; employment; access to health care. The most successful projects for providing social assistance to internal migrants in Kharkiv are highlighted in the area of employment and housing. It is argued that the social assistance project „Ruka dopomohy“ (Helping Hand) for helping people who have moved from the conflict zone to Kharkiv has become the most successful in the social sphere. The key objective of the project is to return those unemployed internally displaced persons to the labor market. The „Helping Hand“ project involves engaging participants in economic activity, taking into account the particularities and aspirations of each. 
The focus is on organizational issues in obtaining social services for internal migrants. Thus, they needed additional social services, the creation of additional organizational structures to provide these services: for example, counseling points where they would obtain legal assistance; social and rehabilitation centers; groups where advice from people with similar experience could be shared. The fact is that there were no new social protection services for migrants from the conflict zone created in Kharkiv (as in Ukraine as a whole). Already existing social services have urgently reoriented their activities to help IDPs.

The basic characteristics of the socio-demographic portrait of internal migrants in Kharkiv region are revealed, in particular, a high level of education which requires flexibility in formulating employment strategies. It was internal migrants with higher education who were more successfully employed in Kharkiv. Whereas among the internally displaced persons of the working professions, the percentage of employed persons was much lower. This was due to the fact that the workers in the Donbass (Donetsk and Luhansk regions) mostly had worked in mines. As there are no mines in Kharkiv region, workers who have been displaced have to acquire new skills and look for new jobs that put new tasks before social protection authorities. In Kharkiv, agriculture, processing and trade account for the largest number of employed internal migrants.

Overall, large-scale internal migration in Ukraine has had both objective and subjective consequences for internal migrants. First and foremost, it is about increasing competition in the labor market, affecting locals who have become hosts for displaced people. The demand for rental housing has also increased significantly. Overload of health care and educational institutions began to be observed.

At the same time, in Ukraine the implementation of the state policy on social protection of internal migrants is characterized by fragmentary and lack of strategic vision in solving many issues.

\section{References:}

1. INTERNALLY DISPLACED PERSONS (2015) Ministry of Social Policy of Ukraine Available at: https://www.msp.gov.ua/timeline/Vnutrishno-peremishcheni-osobi.html.
2. GUSEVA N. (2018) Internal Displacement in the Kharkov Region: A National Dimension In: Region-2018: Optimal Development Strategy: Proceedings of an International Scientific and Practical Conference, Kharkiv, 2018, pp. 264-270.

3. ON ENSURING THE RIGHTS AND FREEDOMS OF INTERNALLY DISPLACED PERSONS (2014) Law of Ukraine as of 28.12.2014 Available at: https://zakon.rada. gov.ua/laws/show/1706-18.

4. RINZAK O (2015) Socio-economic adaptation of internally displaced citizens in the host society (on the example of Kharkiv) In: Economics Problems, Vol. 3, 2015 pp 275280.

5. NUMBER OF REGISTERED IDPS AS OF APRIL 13, 2020 (2020) Ministry of Reintegration of Temporarily Occupied Territories of Ukraine Available at: https://mtot.gov. ua/ua/kilkist-zareestrovanih-vpo-stanom-na13-kvitnja-2020-r?fbclid=IwAR0F7cueRDC6OuQtrHFO0KVcPp53eREN9nouGQT 6ry7VMRmEIuKnzBVpQ8.

6. EVDOKIMOVA I (2017) Problems of State and Communal Social Services in Meeting the Needs of Internally Displaced Persons in Kharkiv In: «SOCIOSPACE: the interdisciplinary online collection of scientific works on sociology and social work», Vol. 6, 2017 pp. 39-47.

7. ECONOMIC OPPORTUNITIES FOR VICTIMS OF CONFLICT (2016) Comprehensive sociological research conducted within the framework of the project Kyiv: Ukrainian Women's Fund, 2016174 pp.

8. SOCIAL SUPPORT FOR INTERNALLY DISPLACED PERSONS (2019) Kharkiv State Regional Administration Available at: https://kharkivoda.gov.ua/oblasnaderzhavna-administratsiya/struktura-administratsiyi/strukturni-pidrozdili/139/3017.

9. RUKA DOPOMOHY (2017) Pilot Project of the Ministry of Social Policy of Ukraine Available at: http://rukadopomogu.com.ua/ua.

10. ALINA STARCHENKO'S OWN BUSINESS (2019) State Employment Center Available at: https://www.dcz.gov.ua/publikaciya/vlasnyy-biznes-aliny-starchenko.

11. FOR IDPS (2019) Kharkiv City Center for Social Services for Family, Children and 
Youth «Dovira» Available at: http://dovira. kh.ua/index.php?id_pidkategorii=0\&id_kategorii=11.

12. ANALYTICAL REVIEW OF REGIONAL HOUSING PROGRAMS FOR INTERNALLY DISPLACED PERSONS (2018) United Nations Refugee Agency (UNHCR) Kyiv, 2018, 58 pp. 